\title{
EFFECTIVENESS ANALYSIS OF ANAEROBIC DIGESTION METHOD IN MAKING BIOGAS FROM ANIMAL MANURE AND TOFU LIQUID WASTE
}

\author{
Fahmi Arifan*1) Abdullah $^{2)}$, Siswo Sumardiono ${ }^{2)}$ \\ 1) Industrial Chemical Engineering of Vocational School, Diponegoro University, Jl. Prof. Soedarto, SH., \\ Tembalang, Semarang, 50275, Indonesia \\ 2) Chemical Engineering Department, Dipoengoro University, Jl. Prof. Soedarto, SH., Tembalang, Semarang, \\ 50275, Indonesia \\ *Corresponding Email: fahmiarifan@live.undip.ac.id
}

Submitted 17 March 2021; Accepted 2 June 2021

\begin{abstract}
Organic waste has high COD and BOD content, so it is dangerous if disposed of directly into the environment. Organic waste processing, such as waste from livestock manure and liquid tofu waste, requires a process that can reduce COD and BOD levels as well as produce valuable products. Anaerobic digestion method is the proper process to convert complex compounds in waste into simpler compounds with methanogenic bacteria into a renewable energy product, namely biogas. On the other hand, the anaerobic digestion process can reduce COD and BOD levels in the biogas formation process. This study uses raw materials such as cow manure and chicken manure, and liquid tofu waste. The variables that produced the largest biogas were those with a ratio of $70 \%$ cow dung, $15 \%$ chicken manure, and $15 \%$ tofu liquid waste with a total of $3,251.5 \mathrm{~mL}$. Then, the COD and BOD levels decreased significantly with more than $98 \%$ COD removal, and more than 95\% BOD removal in all variables at the end of the anaerobic digestion process.
\end{abstract}

Keywords: Anaerobic digestion; biogas; waste 


\section{INTRODUCTION}

The energy crisis in this world requires us to innovate in creating renewable energy that is effective and environmentally friendly (Luz et al., 2017). One of the renewable energies being developed is biogas. Biogas contains methane, carbon dioxide, hydrogen sulfide, and water which means it can substitute for kerosene and LPG (Liquid Petroleum Gas). Biogas production depends on raw material and the processing method used (Sanjaya, 2015). One type of raw material used for biogas production is tofu liquid waste which comes from the by-product of the tofu industrial production process. Tofu liquid waste is hazardous if disposed of directly into the environment because it contains high COD and BOD values (Budiyono and Syaichurrozi, 2020). However, tofu liquid waste contains high organic and nutritional substances, making it suitable for processing into biogas using the anaerobic digestion method. If the tofu liquid waste is discharged directly to the water bodies, some problems will occur. The high organic compound (high COD and BOD) will decrease the dissolved oxygen, so it will disturb the aquatic organisms such as fish. The high nitrogen content also results bad odor because of ammonia gas. Its murky color will decrease the water quality and decrease the sunlight penetration to the water plants in which it cannot do photosynthesis process easily. Furthermore, when the water is used for human daily activity, the human can get skin diseases, stomachache, etc. Apart from tofu waste, another raw material that has been widely studied is waste from livestock manure (Sanjaya, 2015). In Indonesia, the most common livestock manure is chicken manure and cow manure. Chicken manure

*Corresponding author:

Fahmi Arifan

Email: fahmiarifan@live.undip.ac.id

Industrial Chemical Engineering of Vocational School, Diponegoro University, Jl. Prof. Soedarto, SH., Tembalang, Semarang, 50275, Indonesia and cow manure are often only used as fertilizer in limited quantities and do not experience an increase in economic value. On the other hand, unused chicken manure and cow dung will cause air pollution that disrupts environmental health.

Anaerobic digestion is a natural biogas formation process that occurs in the absence of oxygen levels. It is usually used to process raw materials from industrial waste, household waste, vegetable waste, and food waste (Kythreotou et al., 2014). Anaerobic digestion is a natural biological process that can convert organic material into biogas products consisting of methane and carbon dioxide. Anaerobic digestion provides a breakthrough in the processing of organic material, which is usually processed through the composting process into a biodegradation process of organic matter without the presence of oxygen. Besides, anaerobic digestion allows the treatment of waste containing high organic matter levels to reduce the load on its organic content. Simultaneously, producing biogas can be used to generate heat, electricity, and biofuel for vehicles (Awe et al., 2017).

Anaerobic digestion processes involve complex dynamic systems of microbiological, biochemical, and physicochemical processes. Among the possible methods for processing biowaste, anaerobic digestion has been identified as the most environmentally friendly because it allows bioenergy and potential by-products (Monson et al., 2007).

Furthermore, from an environmental point of view, anaerobic processes reduce the content of organic matter present in the waste such as COD and BOD, and reduce environmental pollution. Chemical Oxygen Demand (COD) is the quantity of organic compounds in organic matter, which refers to the mass of oxygen depleted per liter. The

How to cite:

Arifan, F., Abdullah., \& Sumardiono, S. (2021). Effectiveness Analysis of Anaerobic Digestion Method in Making Biogas from Animal Manure and Tofu Liquid Waste. Jurnal Ilmu dan Teknologi Hasil Ternak (JITEK), 16 (2), 84-94 
greater the quantity of COD the higher pollution. Higher COD levels mean a greater amount of oxidizable organic material in the sample, which will reduce dissolved oxygen (DO) levels (Kawai et al., 2016). A reduction in DO can lead to anaerobic conditions, which is deleterious to higher aquatic life forms. While, BOD can be defined as the mass of dissolved oxygen demanded by aerobic biological organisms in water body to degrade organic matters. The greater the BOD, the more rapidly oxygen is depleted in the stream. This means less oxygen is available to higher forms of aquatic life. The consequences of high BOD are the same as those for low dissolved oxygen: aquatic organisms become stressed, suffocate, and die (Adou et al., 2020). The presence of COD and BOD can damaged the environment a lot. Therefore, anaerobic digestion treatment is a right way to reduce BOD and COD value. Regarding the energy aspect, the anaerobic digestion process produces high alternative energy when compared to aerobic processes. The process stages in anaerobic digestion are hydrolytic, acidogenic, acetogenic, and methanogenic bacteria. Carbohydrates, lipids, and proteins are broken down by hydrolytic bacteria into sugars, long-chain fatty acids, and amino acids, respectively. Then, these molecules are converted into volatile fatty acids, alcohol, $\mathrm{CO}_{2}$, and $\mathrm{H}_{2}$ in an acidogenic stage. These molecules are further converted by acetogenic bacteria mainly into acetic acid, $\mathrm{H}_{2}$, and $\mathrm{CO}_{2}$. Finally, all of these products are converted into $\mathrm{CH}_{2}, \mathrm{CO}_{2}$, and water at the last stage, where there is methanogenic bacterial activity (Kwietniewska and Tys, 2014).

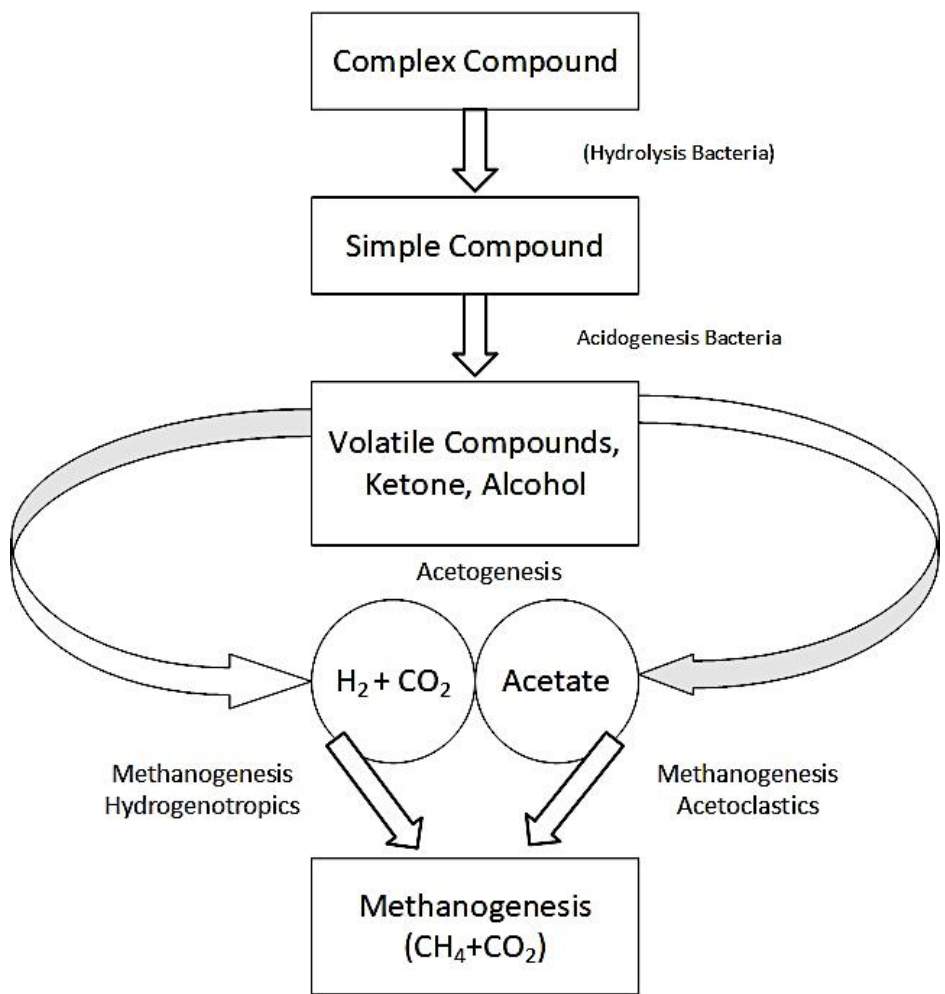

Figure 1. Anaerobic Digestion Process (Budiyono and Syaichurrozi, 2020)

In previous studies that used the anaerobic digestion method, many used various kinds of raw materials, such as research conducted by Lestari et al. (2015) using red microalgae raw materials with an intake of 300 liters produced 2305.5 liters of biogas for 72 days of observation. Novita $e t$ al. (2019) conducted a study using coffee processing liquid waste produced average biogas of $83.57 \mathrm{~mL} /$ day. Previous research results can still be improved by using a mixture of tofu liquid waste and livestock manure. This research focused on the effect of the use of anaerobic digestion method on 
the optimization of the yield of biogas production and the reduction of COD and BOD values as an effort to reduce soil and water environmental pollution, using raw materials in the form of a mixture of tofu liquid waste and livestock manure derived from cow dung and chicken manure.

\section{MATERIALS AND METHODS}

This experimental research was conducted in July - October 2020 at the Laboratory of Animal Product Analysis, Faculty of Agriculture and Animal Science, Diponegoro University, Semarang, Indonesia.

\section{Materials}

The raw material for tofu liquid waste is obtained from the by-product of the tofu production process in the Bandungan area,
Central Java, Indonesia. Furthermore, livestock manure in chicken manure and cow dung is obtained from the Faculty of Agriculture and Animal Science, Diponegoro University, Semarang, Indonesia. The tedler was obtained from ShilpEnt Kaipa Enterprises.

\section{Methods \\ Preparation of Raw Materials}

The raw material used here is tofu liquid waste, chicken manure, and cow dung, got from the Faculty of Agriculture and Animal Science, Diponegoro University. Then it is being added with starter in the form of fermented cow manure (30 days fermentation). The starter prepared as much as $200 \mathrm{~mL}$, then the raw materials for tofu liquid waste and livestock manure are added, and variables are made as shown in table 1.

Table 1. Research's Variable

\begin{tabular}{ccccc}
\hline Run & $\begin{array}{c}\text { Starter } \\
(\mathrm{mL})\end{array}$ & $\begin{array}{c}\text { Cow's Manure } \\
(\%)\end{array}$ & $\begin{array}{c}\text { Chicken's Manure } \\
(\%)\end{array}$ & $\begin{array}{c}\text { Liquid Waste of Tofu } \\
(\%)\end{array}$ \\
\hline 1 & 200 & 100 & 0 & 0 \\
2 & 200 & 80 & 10 & 10 \\
3 & 200 & 70 & 15 & 15 \\
4 & 200 & 60 & 20 & 20 \\
\hline
\end{tabular}

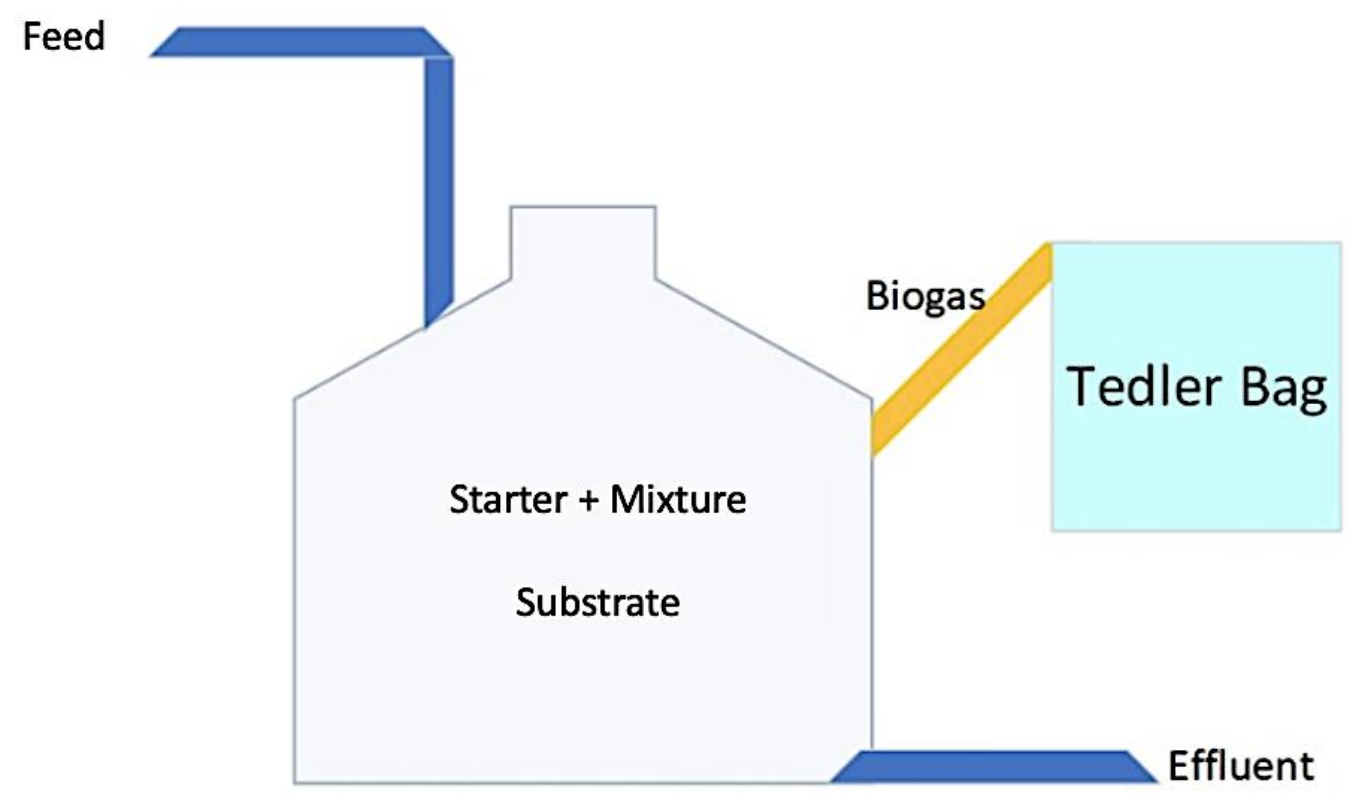

Figure 2. Batch Type Digester Design for Anaerobic Digestion Processes 


\section{Anaerobic Digestion}

The anaerobic digestion method in this study uses a batch type digester. The starter that has been prepared is included in the variable raw material is put in the digester. It is fed with nitrogen gas to remove the oxygen content in the digester. Then the digester being isolated from free air the digester being free from oxygen content in order to make the archaea bacteria can doing a methanogenesis proses properly to produce methane gas and carbondioxide. The digester then being connected with tedler bag to save the gas produced. The biogas that is being keep inside the tedler bag then being measured in volume every 2 days, with total production of 90 days. The batch type digester used can be seen in Figure 2.

\section{Pre-and-Final Analysis of Substrate}

The substrate that enters the digester is analyzed for $\mathrm{pH}, \mathrm{COD}$, and BOD early before production and after biogas production ends. Analysis of $\mathrm{pH}$ using a digital $\mathrm{pH}$ meter (model 526) for three repetitions until the value is constant. Then, analyze the COD content using the standard method from SNI 6989.02: 2019 with the closed reflux method. Then to analyze the content of BOD using standards from SNI 6989.72: 2009.

\section{Measurement of Gas}

The anaerobic digester series designed by using batch system inside $350 \mathrm{~mL}$ glass container and free from $\mathrm{O}_{2}$ component because it has been filled with $\mathrm{N}_{2}$ gases before the fermentation day get started. The digester also connected with tedler bag that save the biogas produced from the fermentation process. After the preparation of digester series added with the mixing substrat and being fulfilled with $\mathrm{N}_{2}$ gases, the fermentation process gets started. Biogas volume measurements are carried out every two days using a measuring cup and a water pump, where the gas will suppress the presence of water in the measuring cup until the volume of gas produced is read. Measurements were carried out for 90 days in every 2 days without any additional substrate during the anaerobic digestion process. The aim is to determine the potential yield of biogas that each variable can produce without adding a substrate in the middle of the production process.

\section{RESULTS AND DISCUSSION}

\section{Analysis of pH}

Measuring the $\mathrm{pH}$ value is carried out before and after the anaerobic digestion process takes place. The measurement results can be seen in Figure 3.

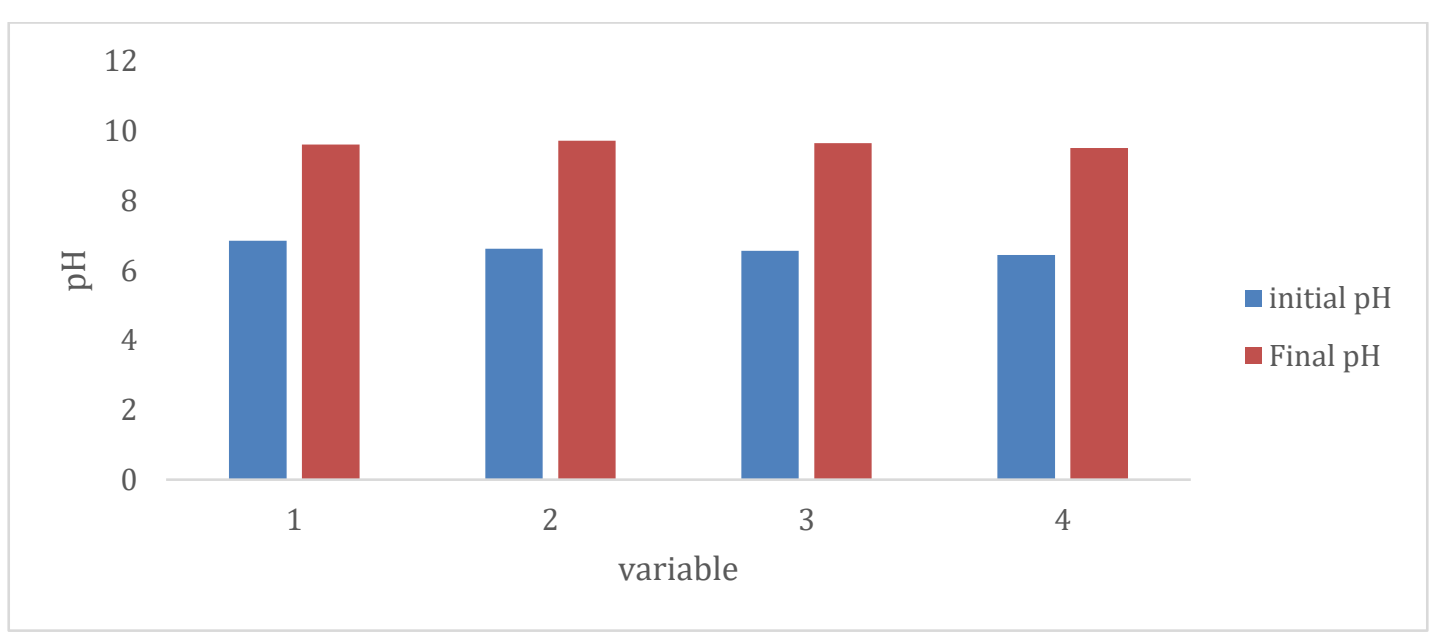

Figure 3. Initial and Final pH Testing on the Digester Substrate 
In the graph, the comparison between the initial $\mathrm{pH}$ and the final $\mathrm{pH}$ has increased at the end. In the beginning, before the anaerobic digestion process is carried out. According to Ramdiana (2017), in the $\mathrm{pH}$ range, 6-6.7, methanogenic bacteria can survive to produce very little gas because the substrate's acidity can kill bacteria so that methane gas is still produced even in small amounts (Ramdiana, 2017). Microorganisms that work in the early stages are microorganisms in the hydrolysisacidogenesis process, which produce volatile acids so that the $\mathrm{pH}$ value decreases (Ni'mah, 2014).

On the next day, the $\mathrm{pH}$ value increased closer to normal conditions. As long as the $\mathrm{pH}$ is still in an acidic state, biogas and $\mathrm{CH}_{4}$ production will continue (Latinwo and Agarry, 2015). After 12 days, all samples' $\mathrm{pH}$ has reached normal from the initial $\mathrm{pH}$, where methanogenic bacteria are gradually more active until the optimal $\mathrm{pH}$ is reached for biogas production (Ni'mah, 2014).

On the $12^{\text {th }}$ day measurement, it was indicated that the methanogenesis process was going well because methanogenic bacteria could produce methane at a $\mathrm{pH}$ of 6.8-8.5 (Ramdiana, 2017). The results at the final study $\mathrm{pH}$ tended to rise for all variables compared to the baseline test. This can occur because methanogenic bacteria cannot work in acidic conditions to increase the $\mathrm{pH}$. The optimum conditions for $\mathrm{pH}$ to produce biogas are at $\mathrm{pH}$ 6.8-7.2. However, up to a $\mathrm{pH}$ of 8.5 , it will still produce biogas even though it decreases. The longer the operation time and the higher the $\mathrm{pH}$, the lower the amount of biogas production so that the biogas production in this study began to stop on the day of 60 .

\section{Chemical Oxygen Demand (COD) Analysis}

Determination of COD value before and after the process is intended to determine the anaerobic digestion method's effectiveness. The results of the COD analysis can be seen in Figure 4. COD or Chemical Oxygen Demand is the amount of oxygen needed to chemically break down all organic materials contained in the water (Santoso, 2018). At the beginning of the experiment, the variable that had the highest COD content was the B4 variable with $660,000 \mathrm{mg} / \mathrm{L}$. All variables initially have very high COD levels and they are very dangerous if disposed of directly into the environment. Therefore, the biogas formation process can reduce COD levels in the mixture of ingredients. From this data, it can be said that the COD value in each digester has decreased during the fermentation process. The value of COD removal in variable $\mathrm{B} 2$ shows that the number of organic compounds that can be chemically oxidized in variable B2 is higher than the other variables. According to Atima (2015), the decrease in COD value was caused by the hydrolysis process. At this stage, the organic material is used by microorganisms as nutrients and converts into simpler compounds so that the COD value can decrease significantly. The COD removal for variable 1-4 calculated as $98,02 \%$; $98.48 \%$; 98,63 ; and $98.93 \%$ respectively.

It shows that anaerobic digestion is an effective way for COD removal on tofu liquid waste and the mixing of manure waste used as the substrat in this experiment. Based on the research done by (Kawai et al., 2016), which is doing COD removal on recalcitrant waste water, the removal efficiencies of COD of the land fill leachate at Phase 5 (80-90 days of production) remained relatively high at $26 \%$ and $30 \%$, respectively, and these values were 1.4 times and 3.0 times higher than those of Phase 3 (40-50 days of production). It shows that the longer time takes for anaerobic process, the COD value will decrease more. This research may not calculate the COD values in each day to know the graph of COD reduction day by day, but, the results already appropriate with the references that anaerobic digester shows an effective results for COD reduction because in the end of the process, the COD of the substrate has decreased significantly. 


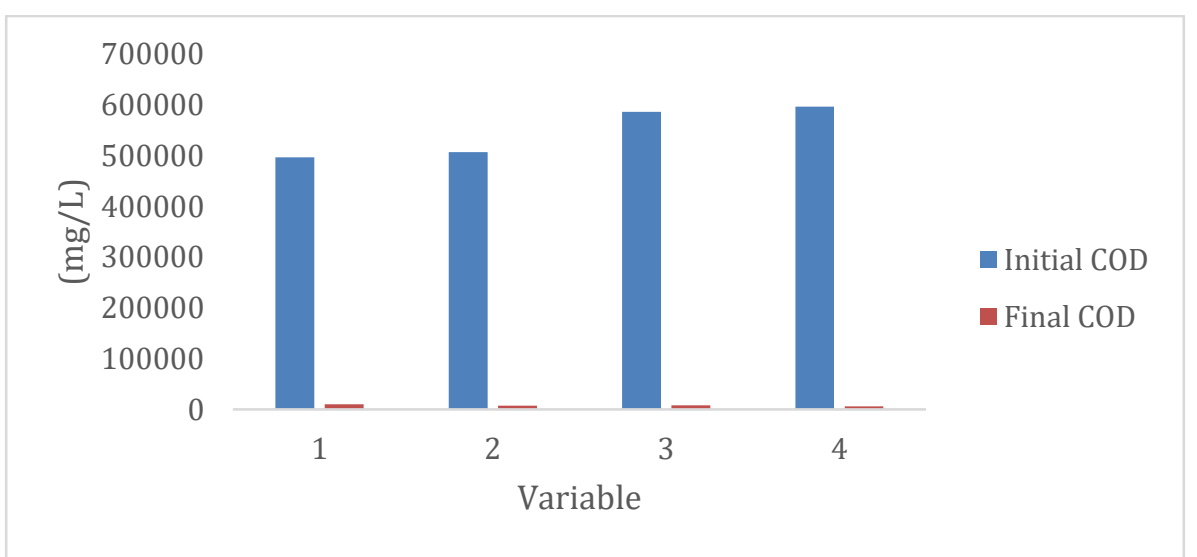

Figure 4. Initial and Final COD Tests on the Digester Substrate

\section{Biological Oxygen Demand (BOD) Analysis}

The BOD test value is carried out before and after the anaerobic digestion process, which can be seen in Figure 5. Biological Oxygen Demand (BOD) is defined as the oxygen requirement for microorganisms to oxidize chemical compounds. The greater the BOD, the more rapidly oxygen is depleted in the stream. This means less oxygen is available to higher forms of aquatic life. The consequences of high BOD are the same as those for low dissolved oxygen: aquatic organisms become stressed, suffocate, and die. The BOD value in the substrate at the beginning of the process was quite high, especially variable 4, which reached $184,967 \mathrm{mg} / \mathrm{L}$. It is proven that the BOD test shows a very significant reduction in variable 4 from the initial $184,967 \mathrm{mg} / \mathrm{L}$ to $7,633.33 \mathrm{mg} / \mathrm{L}$. In other variables such as variable 1 , it decreased from $153,967 \mathrm{mg} / \mathrm{L}$ to $6,530 \mathrm{mg} / \mathrm{L}$. Then in variable 2 , which initially had a BOD value of $157,067 \mathrm{mg} / \mathrm{L}$, it fell to $6300 \mathrm{mg} / \mathrm{L}$. Variable 3, the BOD value decreased from $181867 \mathrm{mg} / \mathrm{L}$ to $7350 \mathrm{mg} / \mathrm{L}$. The BOD removal for variable $1-4$ calculated as $95,75 \%$; $95.98 \%$; 95,95; and $95.87 \%$ respectively. It shows that anaerobic digestion is an effective way for BOD removal on tofu liquid waste and the mixing of manure waste used as the substrate in this experiment.

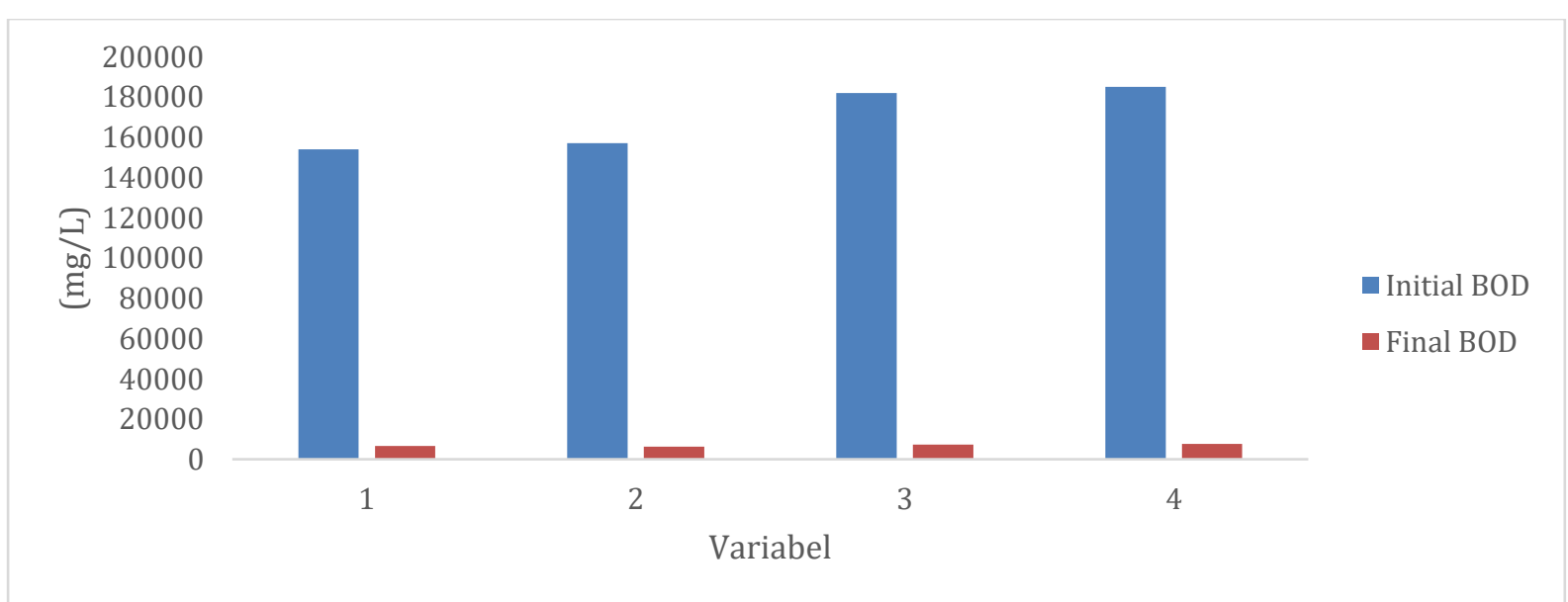

Figure 5. Initial and Final BOD Testing on the Digester Substrate

Through the anaerobic digestion process, hydrolysis fermentation bacteria convert complex organic compounds into simple ones so that the oxygen demand for oxidizing chemical compounds can decrease drastically. Generally, organic matter with 
low level of BOD (less than $300 \mathrm{mg} . \mathrm{L}^{-1}$ ) can be treated effectively using the aerobic system, while wastewater with high level of BOD (more than $300 \mathrm{mg} . \mathrm{L}^{-1}$ ) can be treated well using the anaerobic system (Daud et al., 2018). Thus, considering the high concentration of organic matters in the substrate, anaerobic digestion should be considered as the main BOD removal treatment process. For comparison, the research done by (Adou et al., 2020), the slight removal efficiency of BOD in the first phase of wastewater from the main slaughterhouse resulted from the predominance of hydrolysis. According to (Ometto et al., 2019), low hydrolysis rate may be a limiting step of AD when complex structures remain undigested and are not available for AD. The improvement of BOD removals during the second phase resulted from the ideal conditions of methanogenesis with $\mathrm{pH}$ values between 7.54 and 8.01. Before $\mathrm{AD}$, the $\mathrm{BOD}$ value was $6750 \pm$ $500 \mathrm{mg} . \mathrm{L}^{-1}$, and after $\mathrm{AD}$, the $\mathrm{BOD}$ value became $1200 \pm 500 \mathrm{mg} . \mathrm{L}^{-1}$.

\section{Daily Measurement of Biogas}

The volume of biogas produced in the tedler bag is measured every 2 two days, and the data can be seen in Figure 6. In variable 1, the Lag phase for variable 1 in the graph is on day 2 to 10 , followed by an exponential phase from day 10 to 18 . Then it is continued with a stationary phase for 4 days until day 22. On day 24, anaerobic bacteria began to experience death, so that biogas production began to decline every day.

And on day 68 to day 90, there is no more gas production. In variable 2 , the lag phase occurs from day 2-8, while the exponential phase happens from day 8-20, and the stationary phase occurs from day 2028 , and on day 66-90, there is no gas production. In variable 3 , the lag phase occurs on days $2-8$, then the exponential phase occurs on days 8-20, and the stationary phase occurs on days 20-30. Biogas production in variable 3 starts to stop on day 70. And in the fourth variable, the lag phase occurs from days 2-8, the exponential phase from days 8-26.

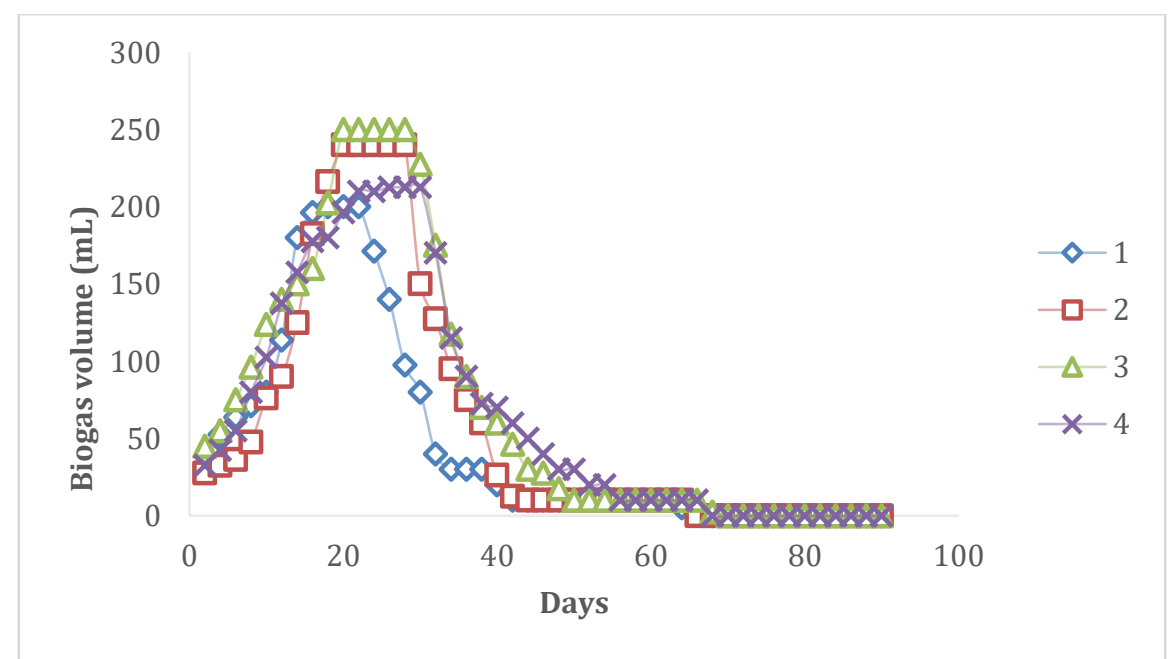

Figure 6. Daily Measurement of Biogas Production

The stationary phase occurs on days 26-30 and has decreased until the $68^{\text {th }}$ day is no longer producing biogas. The biogas results contain methane $\left(\mathrm{CH}_{4}\right)$ as main product, carbon dioxide $\left(\mathrm{CO}_{2}\right)$ as main by products, and other gas in little amount $(\mathrm{CO}$, $\mathrm{H}_{2}, \mathrm{NH}_{3}$, and $\mathrm{H}_{2} \mathrm{~S}$ ). During lag phase, bacteria adapting to their new environment. The duration of this phase varies and is determined from the composition of the media, $\mathrm{pH}$, temperature, aeration, number of cells, and physiological properties. While the logarithmic or exponential phase is characterized by a period of fairly rapid growth. Each cell in the population divided into two. The degree of bacterial growth in this phase is strongly influenced by hereditary genetic traits. Then for the 
exponential phase, the bacteria stop to growth and the biogas production tend to be constant. The stationary phase is then followed by the death phase, which is marked by an increase in the mortality rate that exceeds the growth rate (Budiyono and Syaichurrozi, 2020).

\section{Cumulative Measurement of Biogas}

The cumulative biogas measurement for variables 1 to 4 is shown in Figure 7. The highest cumulative biogas production is in variable 3 with a composition of $70 \%$ cow dung, $15 \%$ chicken manure, and $15 \%$ tofu liquid waste. Variable 3 produces biogas with an amount of 3,251.5 mL. Furthermore, the next highest biogas production was variable 4 with $3,046.25 \mathrm{~mL}$ with a composition of $60 \%$ cow dung, $20 \%$ chicken manure, and $20 \%$ tofu liquid waste. Furthermore, variable 2 biogas production produces $2690 \mathrm{~mL}$ of biogas. With a composition of $80 \%$ cow dung, $10 \%$ chicken manure, and $10 \%$ tofu liquid waste. For the variable $100 \%$ cow dung, it produces $2146.25 \mathrm{~mL}$ of biogas.

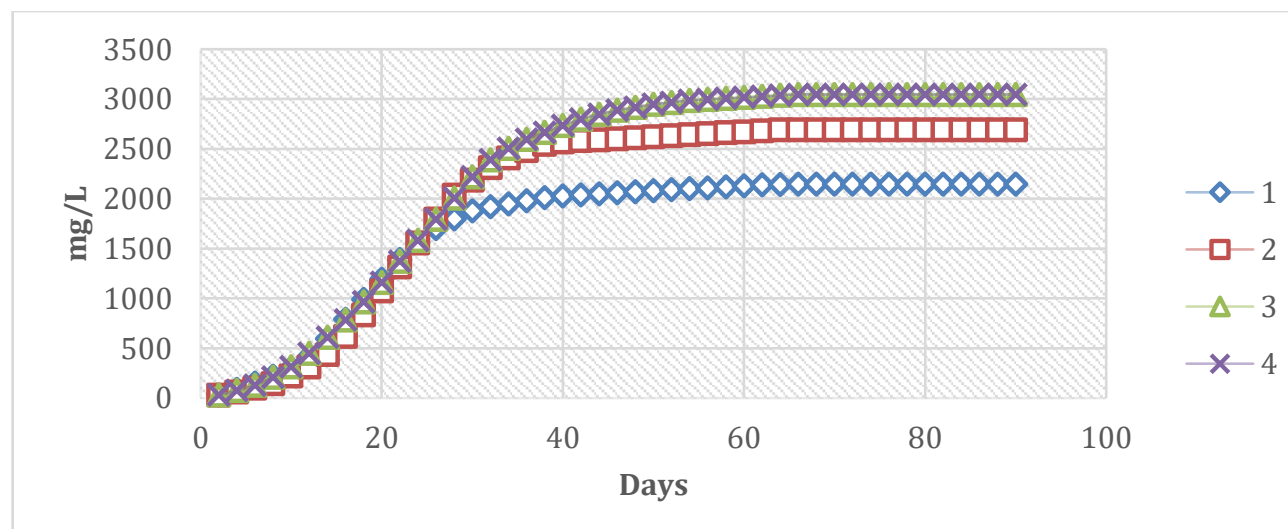

Figure 7. Cumulative Measurement of Biogas Production

The biogas production from metabolism of anaerobic digestion method divided into 4 phase i.e. hydrolysis, acidogenesis, acetogenesis, methanogenesis. In the acidogenesis phase, simple organic compounds are degraded into volatile fatty acids (acetic acid, butyric acid, propionic acid, hydrogen, carbon dioxide, methanol, ethanol). In the acetogenesis phase, propionic acid, butyric acid and ethanol are converted to acetic acid. In methanogenesis, methane and carbon dioxide are formed (Juanga et al., 2007).

\section{CONCLUSION}

Organic waste such as tofu liquid waste, has high COD and BOD content, so it is dangerous if disposed of directly into the environment. Organic waste processing, such as waste from livestock manure and tofu liquid waste, requires a process that can reduce $\mathrm{COD}$ and $\mathrm{BOD}$ levels as well as produce valuable products. Anaerobic digestion method is the proper process to convert complex compounds in waste into simpler compounds with methanogenic archaea bacteria's activity into a biogas as a renewable energy product.

The biogas production from metabolism of anaerobic digestion method divided into 4 phase i.e. hydrolysis, acidogenesis, acetogenesis, methanogenesis. In the acidogenesis phase, simple organic compounds are degraded into volatile fatty acids (acetic acid, butyric acid, propionic acid, hydrogen, carbon dioxide, methanol, ethanol). In the acetogenesis phase, propionic acid, butyric acid and ethanol are converted to acetic acid. In methanogenesis, methane and carbon dioxide are formed. This experimental research used raw materials such as cow dung and chicken manure, and tofu liquid waste as a substrate to produce biogas and at the same time reduce the COD and BOD 
content. It also used glass container as a digester then fulfilled the digester with $\mathrm{N}_{2}$ gas so the digester become anaerobic (no oxygen content).

The process of anaerobic digestion run in 90 days and the biogas volume being measured every 2 The variables that produced the largest biogas were those with a ratio of $70 \%$ cow dung, $15 \%$ chicken manure, and $15 \%$ tofu liquid waste with a total of $3,251.5 \mathrm{~mL}$. Then, the COD and BOD levels decreased significantly with more than $98 \%$ COD removal, and more than $95 \%$ BOD removal in all variables at the end of the anaerobic digestion process.

\section{ACKNOWLEDGMENT}

The authors would like to thank the Diponegoro University for supporting and facilitate the laboratory to run the research.

\section{REFERENCES}

Adou, K. E., Alle, O. A., Kouakou, A. R., Adouby, K., Drogui, P., \& Tyagi, R. D. (2020). Anaerobic mono-digestion of wastewater from the main slaughterhouse in Yamoussoukro (Côte d'Ivoire): Evaluation of biogas potential and removal of organic pollution. Journal of Environmental Chemical Engineering, 8(3), 103770. https://doi. org/10.1016/j.jece.2020.103770

Awe, O. W., Zhao, Y., Nzihou, A., Minh, D. P., \& Lyczko, N. (2017). A review of biogas utilisation, purification and upgrading technologies. Waste and Biomass Valorization, 8(2), 267-283.

Budiyono, B., \& Syaichurrozi, I. (2020). A review: biogas production from tofu liquid waste. IOP Conference Series: Materials Science and Engineering, 845(1), 12047.

Daud, M. K., Rizvi, H., Akram, M. F., Ali, S., Rizwan, M., Nafees, M., \& Jin, Z. S. (2018). Review of upflow anaerobic sludge blanket reactor technology: Effect of different parameters and developments for domestic wastewater treatment. In Journal of Chemistry. https://doi.org/ 10.1155/2018/1596319

Juanga, J. P., Visvanathan, C., \& Tränkler, J. (2007). Optimization of anaerobic digestion of municipal solid waste in combined process and sequential staging. Waste Management and Research, 25(1), 30-38. https://doi. org/10.1177/0734242X07072085

Kawai, M., Nagao, N., Kawasaki, N., Imai, A., \& Toda, T. (2016). Improvement of COD removal by controlling the substrate degradability during the anaerobic digestion of recalcitrant wastewater. Journal of Environmental Management, 181, 838-846. https://doi. org/10.1016/j.jenvman.2016.06.057

Kwietniewska, E., \& Tys, J. (2014). Process characteristics, inhibition factors and methane yields of anaerobic digestion process, with particular focus on microalgal biomass fermentation. Renewable and Sustainable Energy Reviews, 34, 491-500.

Kythreotou, N., Florides, G., \& Tassou, S. A. (2014). A review of simple to scientific models for anaerobic digestion. Renewable Energy, 71(October 2018), 701-714. https:// doi.org/10.1016/j.renene.2014.05.055

Latinwo, G. K., \& Agarry, S. E. (2015). Modelling the kinetics of biogas production from mesophilic anaerobic co-digestion of cow dung with plantain peels. International Journal of Renewable Energy Development. https://doi.org/10.14710/ijred.4.1.55-63

Lestari, D. F., Kawaroe, M., \& Salundik, S. (2015). Produksi biogas dari makroalga merah (Gracilaria verrucossa) pada sistem batch. Jurnal Teknologi Perikanan Dan Kelautan, 6(2), 179-186.

Luz, F. C., Cordiner, S., Manni, A., Mulone, V., \& Rocco, V. (2017). Anaerobic digestion of liquid fraction coffee grounds at laboratory scale: evaluation of the biogas yield. Energy Procedia, 105, 1096-1101. 
Monson, K. D., Esteves, S. R., Guwy, A. J., \& Dinsdale, R. M. (2007). Anaerobic digestion of biodegradable municipal solid wastes a review. Univerisity of Glamorgan.

Ni'mah, L. (2014). Biogas from solid waste of tofu production and cow manure mixture: Composition effect. Chemica, 1(1), 1-9.

Novita, E., Pradana, H. A., Wahyuningsih, S., Marhaenanto, B., Sujarwo, M. W., \& Hafids, M. S. A. (2019). Anaerobic digester variation for biogas production on coffee wastewater treatment. Jurnal Teknik Pertanian Lampung, 8(3), 164-174.

Ometto, F., Karlsson, A., Ejlertsson, J., Björn, A. V., \& Shakeri, S. Y. (2019). Anaerobic digestion: An engineered biological process. In Substitute Natural Gas from Waste: Technical

\section{Assessment and Industrial Applications of Biochemical and Thermochemical Processes. https:// doi.org/10.1016/B978-0-12-81 5554- 7.00005-2}

Ramdiana, R. (2017). Pengaruh Variasi Komposisi Pada Campuran Limbah Cair Aren dan Kotoran Sapi Terhadap Produksi Biogas. Eksergi, 14(2), 12-17.

Sanjaya, D. (2015). Produksi Biogas dari Campuran Kotoran Sapi dengan Kotoran Ayam. Fakultas Pertanian.

Santoso, D. A., 2018. Keragaan Nilai DO, BOD dan COD di danau bekas tambang batubara studi kasus pada danau sangatta north PT. KPC di Kalimatan Timur. Jurnal Teknologi Lingkungan, 19(1).

Wa, A., 2015. BOD dan COD sebagai parameter pencemaran air. Jurnal Biology Science \& Education, 4(1). 